\title{
KARAKTERISTIK GEL TITANIUM TUNGSTAT DAN PENGARUHNYA TERHADAP PELEPASAN RENIUM-188
}

\author{
Duyeh Setiawan, M. Basit \\ Pusat Teknologi Nuklir Bahan dan Radiometri, Jl Taman Sari No 71 Bandung 40132, tlp 022-2503997, \\ faks 2504081 \\ Iwan Hastiawan \\ Jurusan Kimia FMIPA Universitas Padjadjaran, JI Raya Bandung-Sumedang Km 21 Jatinangor 45363, \\ t/p/faks 0227794391 \\ e-mail: d_setiawan@batan.go.id
}

Diterima 31 Januari 2012, diterima dalam bentuk perbaikan 17 Maret 2012, disetujui 22 Maret 2012

\begin{abstract}
ABSTRAK
KARAKTERISTIK GEL TITANIUM TUNGSTAT DAN PENGARUHNYA TERHADAP PELEPASAN RENIUM188. Gel titanium tungstat (TiW) merupakan bahan matriks generator ${ }^{188} \mathrm{~W} /{ }^{188} \mathrm{Re}$ untuk produksi radioisotop renium-188 $\left({ }^{188} \mathrm{Re}\right)$. Gel titanium tungstat diperoleh dengan cara mereaksikan titanil dan tungsten dari kelimpahan isotop alam. Karakteristik gel titanium tungstat yang dikontrol meliputi perbandingan mol Ti:W, pH dan reaksi pemanasan, merupakan tujuan penelitian yang akan dipelajari. Pembuatan gel dilakukan dengan cara "Preformed" menggunakan sasaran $\mathrm{WO}_{3}$ non radioaktif. Sasaran $\mathrm{WO}_{3}$ dibuat larutan amonium tungstat $\left(\mathrm{NH}_{4}\right)_{2} \mathrm{WO}_{4}$ direaksikan dengan titanium tetraklorida $\left(\mathrm{TiCl}_{4}\right)$, diperoleh kondisi optimum terjadi bentuk gel pada perbandingan mol Ti:W = 1:0.7, pH 6 dan reaksi pemanasan pada suhu $60^{\circ} \mathrm{C}$. Gel berwarna putih dikeringkan pada suhu $80^{\circ} \mathrm{C}$ dan $130{ }^{\circ} \mathrm{C}$ selama tiga jam. Karakterisasi dengan X-RD menunjukkan bahwa sifat gel menunjukkan bentuk struktur amorf. Identifikasi dengan FTIR diperoleh puncak-puncak serapan pada $3600-3000 \mathrm{~cm}^{-1}$ dari gugus $-\mathrm{OH}$ yang berikatan dengan titanium dan ikatan W-OH ditunjukkan pada serapan $1600 \mathrm{~cm}^{-1}$ yang lemah, puncak lain pada serapan 600-1100 $\mathrm{cm}^{-1}$ untuk serapan dari W-O. Identifikasi menggunakan metode SEM diperoleh bentuk butiran kasar, rapuh dan homogen. Gel yang telah diiradiasi dalam reaktor pada fluks neutron $\approx 10^{4} \mathrm{n} / \mathrm{cm}^{2} / \mathrm{s}$ selama $89 \mathrm{jam}$, dipaking dalam kolom yang dilengkapi "sintered glass". Radionuklida ${ }^{188} \mathrm{Re}$ yang terbentuk dielusi dengan larutan $\mathrm{NaCl} 0,15 \mathrm{M} \mathrm{pH}$ 5, diperoleh hasil elusi (yield) $60 \%$, mempunyai kemurnian radiokimia lebih besar $95 \%$.
\end{abstract}

Kata kunci : gel titanium tungstat, generator ${ }^{188} \mathrm{~W} /{ }^{188} \mathrm{Re}$, radioisotop ${ }^{188} \mathrm{Re}$.

\begin{abstract}
CHARACTERISTIC OF TITANIUM TUNGSTATE GELS AND ITS INFLUENCE RHENIUM-188 RELEASED. Titanium tungstate (TiW) gels is generator ${ }^{188} \mathrm{~W} / 188 \mathrm{Re}$ matrix material for production of radioisotope renium-188 $\left({ }^{188} \mathrm{Re}\right)$. Titanium tungstate gels obtained by the way of reaction titanil and tungsten from abundance of natural isotope. Characteristic of titanium tungstate gel was controlled covers comparison of mol Ti:W, pH and heating reaction, is purpose of research which will be studied. Production of gel which will be done by the way "Preformed" applied target $\mathrm{WO}_{3}$ non radioactive. Target $\mathrm{WO}_{3}$ is made by solution of amonium tungstat $\left.(\mathrm{NH})_{2}\right)_{2} \mathrm{WO}_{4}$ is reacted with titanium tetrachloride ( $\mathrm{TiCl}_{4}$ ), obtained condition of optimum in the form of gels with Ti:W=1:0.7 mol comparison, $\mathrm{pH} 6$ and heating reaction at temperature $60^{\circ} \mathrm{C}$. Gel is having white colour is dried at temperature 80 ${ }^{\circ} \mathrm{C}$ and $130^{\circ} \mathrm{C}$ during three hours. Characterization with X-RD indicates that titanium tungstate gels character has form of structure amorf. Identification of gels with FTIR shows absorption peaks at $3600-3000 \mathrm{~cm}^{-1}$ from bunch $\mathrm{OH}$ that bond with titanium and bond between W-OH shown to absorption $1600 \mathrm{~cm}^{-1}$ which is weak, other peaks at absorption 600-1100 $\mathrm{cm}^{-1}$ for absorption from W-O. Identified to applied SEM method is obtained rough particle, crumbly and homogen. Gel irradiated in reactor at neutron flux $\approx 10^{4} \mathrm{n} / \mathrm{cm}^{2} / \mathrm{s}$ during 89 hours, packing in columns equiped " sintered glass". Radionuclide ${ }^{188} \mathrm{Re}$ formed elusion by $0,15 \mathrm{M} \mathrm{NaCl}, \mathrm{pH} 5$ solution, obtained result of elusion (yield) is $60 \%$, radiochemical purities more than $95 \%$.
\end{abstract}

Keyword : titanium tungstate gels, generator ${ }^{188} \mathrm{~W} / 188 \mathrm{Re}$, radioisotope ${ }^{188} \mathrm{Re}$ 


\section{PENDAHULUAN}

Qadioisotop renium-188 ( ${ }^{188} \mathrm{Re}$ ) dibidang kesehatan digunakan untuk radioimunoterapi kanker, mengurangi Rrasa nyeri pada sendi tulang, endovasculer brachyterapi untuk mencegah restenosis setelah angioplasty $\left({ }^{1}\right)$. Karakteristik emisi dan sifat fisika ${ }^{188} \mathrm{Re}$ (waktu paro, $\mathrm{T}_{1 / 2}=16,7 \mathrm{jam}$ ) sesuai untuk aplikasi radioterapi, karena memancarkan partikel beta energi maksimum $\left(E_{\text {beta }}=2,12 \mathrm{MeV}\right)$. Pengaruh pancaran beta dari ${ }^{188}$ Re bersifat efektif untuk menembus beberapa milimeter $(\mathrm{mm})$ dan cukup untuk mematikan tumor ${ }^{(2)}$. Selain itu ${ }^{188} \mathrm{Re}$ merupakan pemancar gamma dengan energi rendah $\left(E_{\text {gamma }}=155 \mathrm{keV}\right)$, cocok untuk pencitraan (imaging) dalam diagnosis organ tubuh manusia(3).

Renium-188 bebas pengemban diperoleh dari sistem generator ${ }^{188} \mathrm{~W} /{ }^{188} \mathrm{Re}$ yang serupa dengan generator ${ }^{99} \mathrm{Mo} /{ }^{99 m} \mathrm{Tc}$ untuk produksi ${ }^{99 \mathrm{mTC}} \mathrm{T}$. Radioisotop induk ${ }^{188} \mathrm{~W}\left(\mathrm{~T}_{1 / 2}=69\right.$ hari) meluruh menghasilkan radioisotop anak ${ }^{188} \mathrm{Re}$ diproduksi dalam reaktor nuklir melalui reaksi inti ${ }^{186} \mathrm{~W}(2 \mathrm{n}, \gamma)^{188 \mathrm{~W}}$. Banyak penelitian sudah dikembangkan dari sistem generator ${ }^{188} \mathrm{~W} / 188 \mathrm{Re}$ menggunakan bahan sasaran iradiasi tungsten ( ${ }^{188 \mathrm{~W}}$ ) yang diserap oleh alumina dalam bentuk ${ }^{188} \mathrm{~W}$-tungstat $\left({ }^{188} \mathrm{WO}_{4}{ }^{-}\right)$, dan ${ }^{188} \mathrm{Re}$-perenat $\left({ }^{188} \mathrm{ReO}_{4}\right)$ yang terbentuk kemudian dielusi dengan $\mathrm{NaCl} 0,15 \mathrm{M}^{(4)}$. Penggunaan alumina sebagai matriks generator ${ }^{188} \mathrm{~W} / 188 \mathrm{Re}$ hanya dapat dilakukan terhadap sasaran ${ }^{188} \mathrm{~W}$ yang mempunyai aktivitas jenis tinggi. Ketersediaan aktivitas jenis tinggi ${ }^{188} \mathrm{~W}$ penting sekali untuk produksi generator ${ }^{188} \mathrm{~W} / 188 \mathrm{Re}$ berdasarkan absorben inorganik alumina, mengingat kapasitas serap alumina sangat terbatas atau rendah. Untuk membuat ${ }^{188} \mathrm{~W}$ aktivitas jenis tinggi diperlukan target ${ }^{186} \mathrm{~W}$-enriched ( pengayaan $96 \%{ }^{186} \mathrm{~W}$ ) yang harganya sangat mahal(5,6).

Cara lain menggunakan sasaran ${ }^{188} \mathrm{~W}$ aktivitas jenis rendah sebagai alternatif sistem generator ${ }^{188} \mathrm{~W} / 188 \mathrm{Re}$ adalah menggunakan bahan matriks berupa gel zirkonium atau titanium tungstat dari sasaran yang mempunyai kelimpahan isotop alam. Penggunaan gel generator dari ${ }^{188} \mathrm{~W}$ aktivitas jenis rendah pembuatannya dapat dilakukan dengan cara menyinari ${ }^{186} \mathrm{~W}$-semi enriched $\left(50 \%\right.$ pengayaan $\left.{ }^{186} \mathrm{~W}\right)$, atau secara teoritis target ${ }^{186} \mathrm{~W}$ berasal dari kelimpahan isotop alam $\left(28,6 \%\right.$ kelimpahan $\left.{ }^{186} \mathrm{~W}\right)$ bisa diirradiasi di dalam reaktor dengan fluks neutron sedang atau rendah ${ }^{(7,8)}$. Karakteristik Gel Titanium Tungstat dan pengaruhnya terhadap Pelepasan Renium-188 (Duyeh Setiawan, dkk)

Metode pembuatan gel titanium tungstat telah dilakukan sebelumnya dengan cara Post-formed, yaitu menggunakan sasaran tungsten radioaktif(5). Cara ini diperlukan penanganan dengan menggunakan fasilitas yang dapat meminimalisasi resiko dari paparan radiasi yang berlebihan. Metode dengan cara Pre-formed menggunakan tungsten non radioaktif merupakan alternatif dari cara Post-formed dalam pembuatan gel generator ${ }^{188} \mathrm{~W} / 188 \mathrm{Re}$ berbasis titanium tungstat. Penelitian ini menguraikan karakteristik matriks gel titanium tungstat-188 yang menggunakan tungsten dari kelimpahan isotop alam untuk pengembangan generator ${ }^{188} \mathrm{~W} /{ }^{188} \mathrm{Re}$ dalam produksi radioisotop ${ }^{188} \mathrm{Re}$.

\section{METODOLOGI}

Bahan kimia utama yang digunakan adalah Tungsten(VI) oksida ( $\mathrm{WO}_{3}$, Fluka 95410), Titanium(IV) klorida ( $\mathrm{TiCl}_{4}$, E.Merck 941, 812382), $\mathrm{NH}_{4} \mathrm{OH}$ (E.Merck), $\mathrm{HCl}$ (E.Merck), $\mathrm{H}_{2} \mathrm{O}_{2} 30$ \% (E.Merck), $\mathrm{NaCl} 0,9 \%$ (Ipha), aquabides (Ipha), karbon dioksida kering padat. Fasilitas pendukung yang digunakan adalah reaktor RSG Siwabessy-Batan Serpong untuk keperluan iradiasi (proses radiasi), kolom gelas, gelas kuarsa, kapsul outer/iner aluminium, syringe, vial, neraca analitik, pipet mikro (eppendorf) $1000 \mathrm{ul}$, sentrifuge, $\mathrm{pH}$ meter digital, magnetik stirer Thermolyne Nouva II, oven, X-Ray Difraction $(X-R D)$, Fourier Transform Infra Red (FTIR), Scanning Electron Microscope ( SEM), Multy Channel Analyzer (MCA), Geiger Muller (GM), peralatan gelas yang biasa digunakan dalam laboratorium kimia.

\section{Cara Kerja}

\section{Pembuatan gel titanium tungstat (TiW)}

\section{a. Perlakuan perbandingan $\mathrm{mol}, \mathrm{pH}$ dan suhu reaksi.}

Tungsten oksida $\left(\mathrm{WO}_{3}\right)$ ditimbang masing-masing sebanyak $1 \mathrm{~g}\left(\approx 4,31 \mathrm{mmol} \mathrm{WO}_{3}\right), 2 \mathrm{~g}(\approx 8,63 \mathrm{mmol}$ $\left.\left.\mathrm{WO}_{3}\right), 4 \mathrm{~g}\left(\approx 17,25 \mathrm{mmol} \mathrm{WO}_{3}\right), 6 \mathrm{~g}\left(\approx 25,88 \mathrm{mmol} \mathrm{WO}_{3}\right), 8 \mathrm{~g}(\approx 34,51 \mathrm{mmol} \mathrm{WO})_{3}\right)$ dan $10 \mathrm{~g}\left(\approx 43,13 \mathrm{mmol} \mathrm{WO}_{3}\right)$, 
kemudian dilarutkan dalam $50 \mathrm{~mL} \mathrm{NH}{ }_{4} \mathrm{OH} 8 \mathrm{M}$, selanjutnya ditambah $10 \mathrm{~mL} \mathrm{H}_{2} \mathrm{O}_{2} 30 \%$ sambil dipanaskan pada suhu $80{ }^{\circ} \mathrm{C}$ sampai jernih. Setelah dingin masing-masing larutan tungstat dicampurkan dengan $4 \mathrm{~mL} \mathrm{TiCl} 4$ $(\approx 36,39 \mathrm{mmol})$ yang didinginkan menggunakan karbon dioksida padat kering $\left(\mathrm{CO}_{2}\right.$ padat $\left.\approx-25{ }^{\circ} \mathrm{C}\right)$. Prosedur diulangi dengan menimbang tungsten oksida $\left(6 \mathrm{~g} \approx 25,88 \mathrm{mmol} \mathrm{WO}_{3}\right)$ sebanyak 7 kali untuk perlakuan variasi $\mathrm{pH}$ $(2,3,4,5,6,7,8)$, kemudian 6 kali untuk perlakuan variasi suhu reaksi $\left(40,50,60,70,80\right.$ dan $\left.90{ }^{\circ} \mathrm{C}\right)$. Pengaturan $\mathrm{pH}$ dilakukan dengan penambahan $\mathrm{HCl} 10 \mathrm{M}$ dan masing-masing lama pemanasan selama 4 jam. Selanjutnya gel titanium tungstat yang berwarna putih disaring menggunakan kertas saring Whatman No 42, lalu dicuci dengan air sampai bebas ion klorida ( tes kualitatif dilakukan dengan mengambil sebanyak 3 tetes filtrat hasil cucian terakhir ditempatkan pada plat tetes kemudian ditambah 3 tetes $\mathrm{HNO}_{3} 0,1 \mathrm{~N}$ dan 3 tetes $\mathrm{AgNO}_{3} 1 \mathrm{~N}$, jika tidak terjadi endapan putih dari $\mathrm{AgCl}$ berarti sudah bebas ion klorida ). Kemudian gel titanium tungstat hasil masing-masing perlakuan dikeringkan dalam oven pada suhu $80^{\circ} \mathrm{C}$ selama 3 jam.

\section{b. Karakterisasi gel titanium tungstat (TiW) pada kondisi optimum}

Tungsten oksida $\left(\mathrm{WO}_{3}\right)$ ditimbang $6 \mathrm{~g}\left(\approx 25,88 \mathrm{mmol} \mathrm{WO}_{3}\right)$, kemudian dilarutkan dalam $50 \mathrm{~mL} \mathrm{NH} \mathrm{NH}_{4} \mathrm{OH}$ $\mathrm{M}$, selanjutnya ditambah $10 \mathrm{~mL} \mathrm{H}_{2} \mathrm{O}_{2} 30 \%$ sambil dipanaskan pada suhu $80{ }^{\circ} \mathrm{C}$ sampai jernih. Setelah dingin masing-masing larutan tungstat dicampurkan dengan $4 \mathrm{~mL} \mathrm{TiCl}_{4}(\approx 36,39 \mathrm{mmol})$ yang didinginkan menggunakan karbon dioksida padat kering $\left(\mathrm{CO}_{2}\right.$ padat $\left.\approx-25^{\circ} \mathrm{C}\right)$. Kemudian diatur $\mathrm{pH} 6$ dengan cara penambahan beberapa tetes $\mathrm{HCl} 10 \mathrm{M}$, selanjutnya dipanaskan pada suhu reaksi $60{ }^{\circ} \mathrm{C}$ selama 4 jam. Selanjutnya gel titanium tungstat yang berwarna putih disaring dan dikeringkan seperti pada item 3.1.1 di atas. Gel titanium tungstat dikarakteristik menggunakan metode X-RD untuk menentukan bentuk struktur, FTIR untuk identifikasi gugus fungsi dan SEM untuk menentukan sifat morfologi.

\section{Irradiasi gel TiW}

Sebanyak $1 \mathrm{~g}$ gel titanium tungstat (TiW) hasil dari pembuatan item 3.1.2 dibungkus dalam aluminium foil kemudian dimasukkan kedalam gelas kuarsa lalu ditutup dengan cara pengelasan. Gelas kuarsa ditempatkan dalam inner capsule yang terbuat dari bahan aluminium nuclear grade, lalu ditutup dengan cara pengelasan. Selanjutnya dilakukan uji kebocoran dengan metode gelembung dalam media air sampai tekanan minus 30 inci $\mathrm{Hg}$. Setelah lolos uji kebocoran, selanjutnya inner capsule dimasukkan ke dalam outer capsule untuk diirradiasi dalam reaktor RSG-GA Siwabessy Batan Serpong pada posisi iradiasi CIP (Centre Irradiation Position) dengan fluks neutron $\approx 10^{14} \mathrm{n} / \mathrm{cm}^{2} / \mathrm{s}$ selama $89 \mathrm{jam}$. Aktivitas ${ }^{188} \mathrm{~W}$ dan ${ }^{188} \mathrm{Re}$ diukur dengan ionisasi chamber.

\section{Profil Elusi ${ }^{188}$ Re dan uji kemurnian}

Gel yang telah diiradiasi dan didinginkan lalu dikemas ke dalam kolom gelas dengan ukuran $6 \mathrm{~mm}$ i.d (diameter dalam) x panjang $25 \mathrm{~mm}$, selanjutnya gel dielusi masing-masing dengan $1 \mathrm{~mL}$ larutan $\mathrm{NaCl} 0,15 \mathrm{M}$, pH 5. Eluat diukur keradioaktifannya dengan detektor HPGe yang dirangkai dengan penganalisis cacahan multi saluran (MCA = Multi Channel Analyzer). Uji kemurnian radiokimia ${ }^{188} \mathrm{Re}$ dengan metode kromatografi lapis tipis (ITLC = Instant Tin Layer Chromatography)(13), sebagai fase diam digunakan ITLCTM_SG $(1 \times 10 \mathrm{~cm})$ dan sebagai fase gerak digunakan pelarut aseton. Cuplikan $\mathrm{Na}^{188} \mathrm{ReO}_{4}$ ditotolkan di kertas pada skala nol, lalu dikeringkan dan dimasukan ke dalam bejana kromatografi sampai ujung kertas tercelup sehingga terelusi oleh eluen sampai skala 10. Selanjutnya kertas dikeluarkan dari bejana, lalu dikeringkan di oven. Kemudian kertas dipotong-potong setiap cm-nya lalu diukur keradioaktifannya menggunakan alat Geiger counter. ${ }^{188} \mathrm{Re}$-perenat ( ${ }^{188} \mathrm{ReO}_{4}{ }^{-}$) diperoleh $\mathrm{Rf}=1,0$.

\section{HASIL DAN PEMBAHASAN}

Pembahasan karakterisasi gel titanium tungstat meliputi penentuan bentuk struktur gel menggunakan teknik X-Ray Difraction (X-RD), identifikasi ikatan-ikatan kimia dalam gel menggunakan teknik Fourier TransformInfra Red ( FT-IR ), dan sifat morfologi gel menggunakan teknik Scanning Electron Microscope ( SEM ), serta profil elusi ${ }^{188} \mathrm{Re}$ dari matriks gel titanium tungstat dilakukan secara menyeluruh karena hasil karakterisasi satu dengan yang lainnya saling berkaitan dalam menentukan karakteristik gel titanium tungstat. Gel titanium tungstat dibuat dengan cara melarutkan tungsten oksida $\left(\mathrm{WO}_{3}\right)$ dengan larutan $\mathrm{NH}_{4} \mathrm{OH}$ selanjutnya ditambah $\mathrm{TiCl}_{4}$ seperti reaksi di bawah ini(9):

$$
2 \mathrm{NH}_{4} \mathrm{OH}+\mathrm{WO}_{3} \rightarrow\left(\mathrm{NH}_{4}\right)_{2} \mathrm{WO}_{4}+\mathrm{H}_{2} \mathrm{O}
$$




$$
2\left(\mathrm{NH}_{4}\right)_{2} \mathrm{WO}_{4}+\mathrm{TiCl}_{4}+3 \mathrm{H}_{2} \mathrm{O} \rightarrow \mathrm{TiW}_{2} \mathrm{O}_{7}(\mathrm{OH})_{2}\left(\mathrm{H}_{2} \mathrm{O}\right)_{2(\text { gel) }}+4 \mathrm{NH}_{4} \mathrm{Cl}
$$

Pembuatan gel dilakukan melalui beberapa tahap variasi parameter antara lain perbandingan $\mathrm{mol}, \mathrm{pH}$ dan suhu reaksi.

\section{Pembuatan gel titanium tungstat (TiW)}

Perbandingan konsentrasi larutan titanium dan tungstat dilakukan variasi dengan menaikkan konsentrasi $\mathrm{WO}_{3}$. Gel kering dari masing-masing perbandingan mol menunjukkan bobot yang bervariasi, karena sistem gel titanium tungstat merupakan senyawa yang tidak stoikiometri dan rendemen yang dihasilkan tidak beraturan mengikuti perubahan perbandingan mol.

Bobot gel titanium tungstat berdasarkan hasil perbandingan konsentrasi Ti:W dengan cara gravimetri dirangkum seperti dalam Tabel 1.

Tabel 1. Kondisi sintesis gel titanium tungstat pada variasi konsentrasi/mol dan perolehan bobot gel kering.

\begin{tabular}{ccccccc}
\hline \multirow{2}{*}{ [TiCL4] mmol } & \multirow{2}{*}{$\left.\mathrm{WO}_{3}\right] \mathrm{mmol}$} & \multirow{2}{*}{$\mathrm{Ti}]:[\mathrm{W}]$} & $\mathrm{pH}$ & \multicolumn{2}{c}{ Bobot Gel $(\mathrm{g})$} & Rendemen, $(\%)$ \\
\cline { 5 - 7 } & 4,31 & $1: 0,12$ & 2,0 & 2,58 & 1,25 & 48,45 \\
36,39 & 8,63 & $1: 0,24$ & 3,5 & 5,16 & 1,62 & 62,79 \\
36,39 & 17,25 & $1: 0,47$ & 4,0 & 10,31 & 6,76 & 65,57 \\
36,39 & 25,88 & $1: 0,71$ & 5,5 & 15,47 & 10,95 & 70,78 \\
36,39 & 34,51 & $1: 0,95$ & 6,5 & 20,62 & 14,40 & 69,84 \\
36,39 & 43,13 & $1: 1,19$ & 7,0 & 25,77 & 17,82 & 69,15 \\
\hline
\end{tabular}

Tabel 1 menunjukkan bahwa pembentukan gel pada perbandingan mol Ti : W $(1: 0,71 ; 1: 0,95$ dan 1 : $1,19)$ diperoleh rendemen satu dengan yang lainnya tidak ada perbedaan yang signifikan. Hasil percobaan sebelumnya dengan perbandingan $\mathrm{Ti}: \mathrm{W}=1: 1$ diperoleh rendemen $76 \%(5)$. Pada percobaan ini kondisi optimum pembuatan gel diperoleh pada perbandingan $\mathrm{mol} \mathrm{Ti}: \mathrm{W}=1: 0,71$, karena secara kualitatif gel dengan rendemen tertinggi dianggap paling optimal dan didukung dengan hasil pengamatan secara visual atau sifat fisik bahwa gel terlihat paling amorf dengan warna putih, rapuh, butiran kasar dan homogen $(5,9,10)$.

Lingkungan reaksi yang berkaitan dengan $\mathrm{pH}$ pada pembentukan gel titanium tungstat akan memberikan pengaruh terhadap berat gel percobaan. Hasil pembentukan gel titanium tungstat pada variasi $\mathrm{pH}$ dirangkum dalam Tabel 2.

Tabel 2. Kondisi sintesis gel titanium tungstat (TiW) pada variasi $\mathrm{pH}$.

\begin{tabular}{cccccc}
\hline $\mathrm{pH}$ & {$\left[\mathrm{TiCL}_{4}\right] \mathrm{mmol}$} & {$\left[\mathrm{WO}_{3}\right] \mathrm{mmol}$} & Berat Gel TiW teori $(\mathrm{g})$ & Berat Gel TiW percobaan $(\mathrm{g})$ & Rendemen $(\%)$ \\
\hline 2 & 36,39 & 25,88 & 15,47 & 2,93 & 18,94 \\
3 & 36,39 & 25,88 & 15,47 & 8,87 & 57,34 \\
4 & 36,39 & 25,88 & 15,47 & 10,84 & 70,07 \\
5 & 36,39 & 25,88 & 15,47 & 10,66 & 68,91 \\
6 & 36,39 & 25,88 & 15,47 & 11,81 & 76,34 \\
7 & 36,39 & 25,88 & 15,47 & 10,66 & 68,91 \\
8 & 36,39 & 25,88 & 15,47 & 9,50 & 61,41 \\
\hline
\end{tabular}

Tabel 2 menunjukkan bahwa pada $\mathrm{pH} 2$ gel yang terbentuk dapat larut kembali sehingga rendemen yang diperoleh menjadi kecil, dan pH 6 diperoleh rendemen paling tinggi sebesar 76,34\%, sedangkan pH > 6 terjadi penurunan rendemen yang disebabkan semakin sedikit muatan ion tungstat sehingga akan sedikit berikatan dengan titanil(5). 
Pada tahap pencarian suhu reaksi optimum pembentukan gel titanium tungstat dilakukan pada perbandingan mol dan $\mathrm{pH}$ optimum. Berdasarkan hasil percobaan, kenaikan suhu tidak berpengaruh secara signifikan terhadap bobot gel titanium tungstat yang diperoleh. Seperti yang dirangkum dalam Tabel 3 .

Tabel 3. Kondisi sintesis gel titanium tungstat pada variasi suhu reaksi

\begin{tabular}{cccccc}
\hline Tmp. $\left({ }^{\circ} \mathrm{C}\right)$ & {$[\mathrm{Ti}] \mathrm{mmol}$} & {$[\mathrm{W}] \mathrm{mmol}$} & Berat Gel TiW teori $(\mathrm{g})$ & Berat Gel TiW percobaan $(\mathrm{g})$ & Rendemen $(\%)$ \\
\hline 40 & 36,39 & 25,88 & 15,47 & 8,54 & 55,20 \\
50 & 36,39 & 25,88 & 15,47 & 10,52 & 68,00 \\
60 & 36,39 & 25,88 & 15,47 & 10,84 & 70,07 \\
70 & 36,39 & 25,88 & 15,47 & 10,76 & 69,55 \\
80 & 36,39 & 25,88 & 15,47 & 10,48 & 67,74 \\
90 & 36,39 & 25,88 & 15,47 & 8,62 & 55,72 \\
\hline
\end{tabular}

Tabel 3 menunjukkan bahwa suhu reaksi pada $60{ }^{\circ} \mathrm{C}$ diperoleh rendemen paling besar $70,07 \%$. Pada suhu reaksi $80^{\circ} \mathrm{C}$ ke atas, secara fisik teramati terbentuknya endapan cenderung mengkristal, sedangkan pada suhu lainnya perbedaan yang tampak adalah pada kondisi fisik serbuknya seperti dirangkum dalam Tabel 4 .

Tabel 4. Bobot dan pengamatan sifat fisik gel pada variasi suhu pemanasan.

\begin{tabular}{ccccl}
\hline Tmp. ( $\left.{ }^{\circ} \mathrm{C}\right)$ & {$[\mathrm{Ti}] \mathrm{mmol}$} & {$[\mathrm{W}] \mathrm{mmol}$} & Berat Gel TiW percob(g) & \multicolumn{1}{c}{ Sifat fisik Gel TiW } \\
\hline 40 & 36,39 & 25,88 & 8,54 & Putih, rapuh, butiran tidak homogen \\
50 & 36,39 & 25,88 & 10,52 & Putih, rapuh, butiran kasar, homogen \\
60 & 36,39 & 25,88 & 10,84 & Putih, rapuh, butiran kasar, homogen \\
70 & 36,39 & 25,88 & 10,76 & Putih, rapuh, butiran halus, homogen \\
80 & 36,39 & 25,88 & 10,48 & Putih, agak keras, butiran kasar, tidak homogen \\
90 & 36,39 & 25,88 & 8,62 & Putih, keras, kristal, tidak homogen \\
\hline
\end{tabular}

Fenomena kristalisasi dipengaruhi oleh kenaikan suhu/pemanasan gel yang menyebabkan semakin kuat ikatan yang terjadi dalam senyawa gel titanium tungstat sehingga struktur amorf berubah menjadi kristal. Apabila gel dikeringkan pada suhu $130{ }^{\circ} \mathrm{C}$, maka terjadi perubahan bentuk struktur melalui reaksi dehidrasi-oksolasi atau kehilangan gugus $-\mathrm{OH}$ dalam gel titanium tungstat $\left[\mathrm{TiW}_{2} \mathrm{O}_{7}(\mathrm{OH})_{2}\left(\mathrm{H}_{2} \mathrm{O}\right)_{2}\right]_{\text {amorf }}$ menjadi $\left[\mathrm{TiW}_{2} \mathrm{O}_{8}\right]_{\text {kristal }}{ }^{(11)}$.

Gambar 1 (a) adalah difraksi sinar-X gel titanium tungstat $\left(\mathrm{TiW}_{2} \mathrm{O}_{7}(\mathrm{OH})_{2}\left(\mathrm{H}_{2} \mathrm{O}\right)_{2}\right.$ menunjukkan bentuk amorf, yaitu ditandai dengan tidak adanya intensitas dari puncak-puncak difraksi. Sedangkan struktur gel titanium tungstat cenderung berubah menjadi semi kristal $\left(\mathrm{TiW}_{2} \mathrm{O}_{8}\right)$, apabila gel dikeringkan pada suhu di atas $130{ }^{\circ} \mathrm{C}$ seperti ditunjukkan pada Gambar 1 ( b ). Bentuk kristal terjadi akibat dehidrasi dalam gel diikuti dengan reaksi oksolasi ( $\mathrm{Ti}-\mathrm{O}-\mathrm{Ti}$ ) yang akan membentuk suatu jaringan yang kompak. Hal ini menyebabkan ${ }^{188} \mathrm{Re}$ sebagai ion ${ }^{188} \mathrm{ReO}_{4}{ }^{-}$akan sulit untuk berdifusi keluar dari matriks gel titanium tungstat-188.

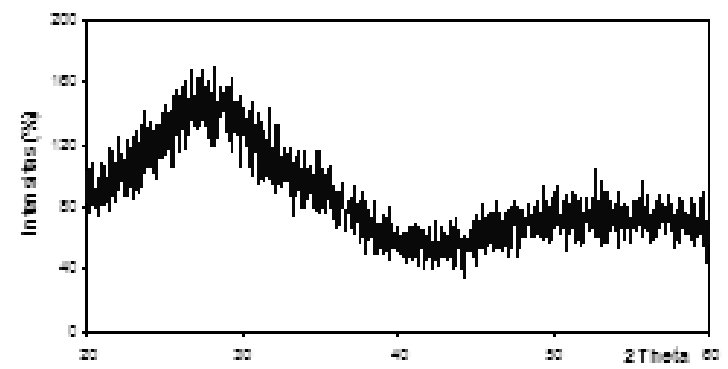

( a )

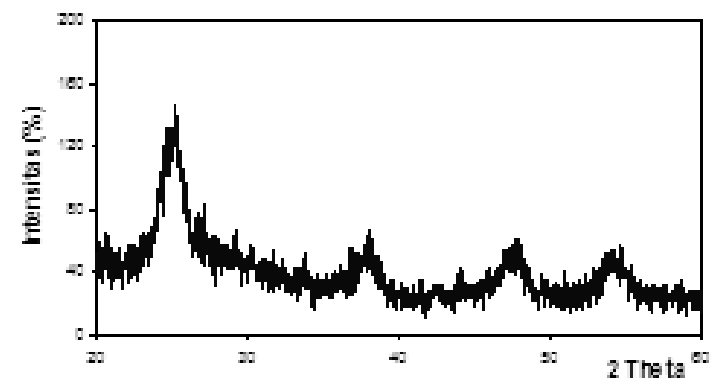

(b)

Gambar 1. Difraktogram gel (a) $\left[\mathrm{TiW}_{2} \mathrm{O}_{7}[\mathrm{OH}]_{2}\left[\mathrm{H}_{2} \mathrm{O}\right]_{2}\right.$, (b) $\mathrm{TiW}_{2} \mathrm{O}_{8}$ 
Berdasarkan hasil identifikasi menggunakan metode spektrofotometri infra merah, spektrum gel titanium tungstat ( Gambar 2 ) memperlihatkan serapan pada daerah $1600 \mathrm{~cm}^{-1}$ yang merupakan serapan untuk ikatan W$\mathrm{OH}$, sedangkan daerah serapan untuk jembatan tungsten - oksigen (W-O) dari 650 - $1000 \mathrm{~cm}^{-1(7)}$ ditunjukkan dalam spektrum yang lemah dan lebar.

Berdasarkan penelitian Le Van So dkk menemukan kompleks L-OH dalam gel titanium molibdat, maka dapat disimpulkan bahwa absorpsi ikatan $\mathrm{L}-\mathrm{OH}$ merupakan absorpsi ikatan $\mathrm{Ti}-\mathrm{OH}$ dan dengan pemanasan atau pemijaran gel akan terbentuk ikatan L-O-L ( L = Logam ) yang ditunjukkan puncak serapan pada daerah 1400 $\mathrm{cm}^{-1}$ akan meningkatkan kekompakan struktur gel tersebut. Molekul gel titanium tungstat ini yang memiliki dua buah kation, maka kekompakan struktur gel tidak hanya dari terbentuknya ikatan Ti-O-Ti tetapi juga dapat diakibatkan dari terbentuknya ikatan Ti-O-W antar molekul(6).

Dari data-data tersebut didapatkan suatu kenyataan bahwa dalam senyawa gel titanium tungstat terikat suatu gugus $-\mathrm{OH}$ dari air. Oleh karena gel kering titanium tungstat sangat hidroskopis, menyebabkan melebarnya spektrum serapan karena adanya molekul air yang terlihat dari pembacaan spektrum infra merah pada daerah $3600-3000 \mathrm{~cm}^{-1}$.

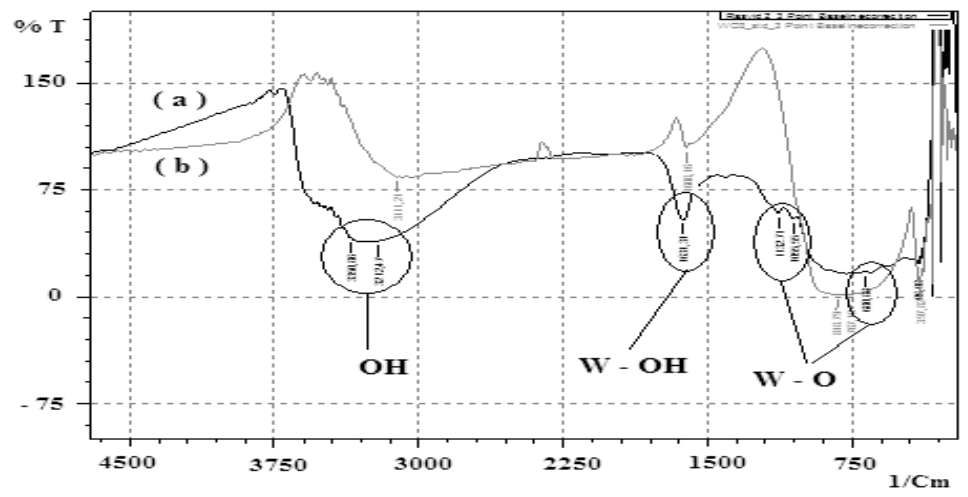

Gambar 2. Spektrum FTIR ( a ) gel titanium tungstat, ( b ) $\mathrm{WO}_{3}$

Karakterisasi sifat morfologi dari gel titanium tungstat dengan menggunakan teknik SEM diperoleh data sesuai dengan hasil pengamatan secara fisik, yaitu mempunyai warna puth, rapuh, bentuk butiran kasar dan homogen ${ }^{(10)}$. Hasil analisis dengan teknik tersebut ditunjukkan pada Gambar 3.

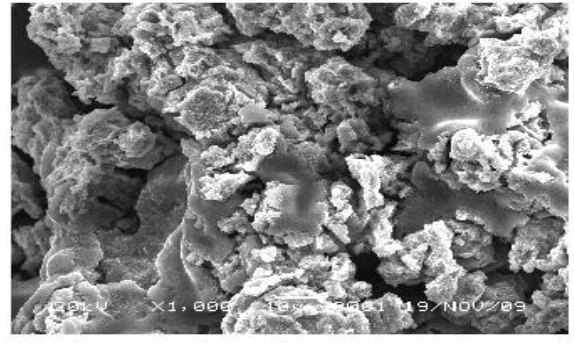

( a )

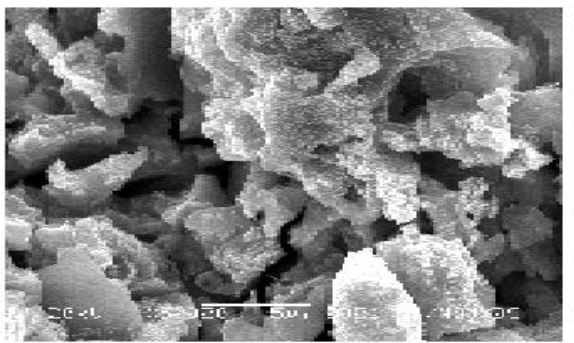

(c)

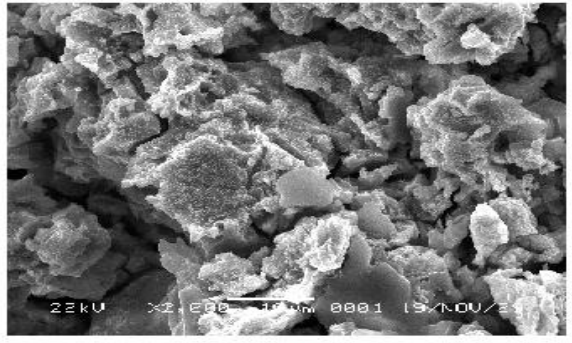

( b )

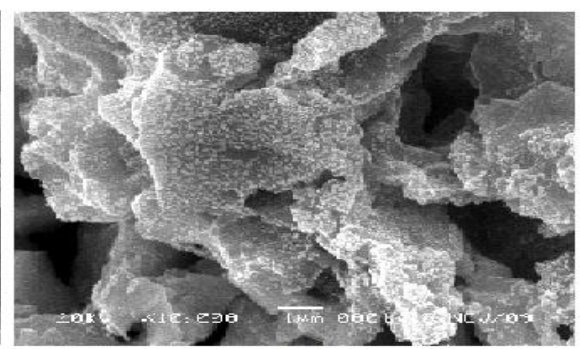

(d)

Gambar 3. Bentuk morfologi gel titanium tungstat (a) 1000 x, (b) 2000 x, (c) 5000 x dan (d) 10.000 x. 


\section{Profil Elusi ${ }^{188}$ Re dan uji kemurnian}

Pelepasan radionuklida ${ }^{188} \mathrm{Re}$ dari gel sebagai matriks generator ${ }^{188} \mathrm{~W} / 188 \mathrm{Re}$ dilakukan dengan cara elusi dengan $\mathrm{NaCl} 0,15 \mathrm{M} \mathrm{pH} 5(\mathrm{NaCl}$ 0,9\%). Setiap eluat yang dihasilkan memberikan aktivitas radioaktif yang menurun untuk setiap elusi seperti yang ditunjukkan pada Gambar 4.

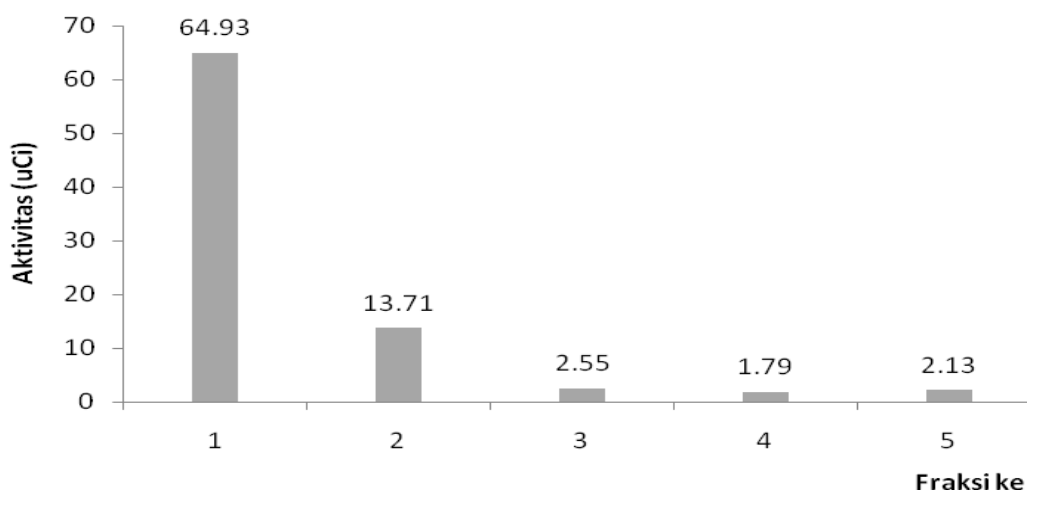

Gambar 4. Profil elusi ${ }^{188} \mathrm{Re}$ menggunakan eluen $\mathrm{NaCl} 0,15 \mathrm{M}$, pH 5

Penampilan generator yang baik pada umumnya menghasilkan sekitar $80 \%$ produk diperoleh dari volume eluat awal(10). Hal ini disebabkan oleh kondisi matriks gel yang kering pada elusi pertama, sehingga dibutuhkan waktu yang lama untuk membasahi matriks gel (5-10 menit) dan lamanya kontak eluen dengan matriks gel menyebabkan produk ${ }^{188}$ Re yang terelusi lebih banyak dari pada elusi ke dua dan selanjutnya yang rata-rata memerlukan waktu yang lebih singkat (2-5 menit).

Bervariasinya jumlah ${ }^{188} \mathrm{Re}$ yang dihasilkan oleh setiap matriks gel titanium tungstat pada generator, disebabkan oleh pengaruh $\mathrm{pH}$ eluen yang digunakan terhadap proses pelepasan ${ }^{188} \mathrm{ReO}_{4}$. Hasil percobaan dengan menggunakan eluen $\mathrm{NaCl} 0,15 \mathrm{M}, \mathrm{pH} 5$ memberikan hasil optimum dalam bentuk natrium perrenat $\left(\mathrm{Na}^{188} \mathrm{ReO}_{4}\right)$ mencapai lebih $60 \%$, hasil ini tidak berbeda nyata dengan percobaan sebelumnya ${ }^{10,12)}$. Hal ini diperkirakan ion ${ }^{188} \mathrm{ReO}_{4}^{-}$lepas dari matriks gel dalam bentuk natrium perrenat $\left(\mathrm{Na}^{188} \mathrm{ReO}_{4}\right)$ setelah terjadi pertukaran ion dengan ion $\mathrm{Cl}^{-}$yang berasal dari eluen $\mathrm{NaCl}^{(10)}$.

Uji kemurnian radiokimia ${ }^{188}$ Re dilakukan dengan kromatografi lapis tipis sebagai fase diam digunakan ITLCTM_SG $(1 \times 10 \mathrm{~cm})$ dan sebagai fase gerak digunakan pelarut aseton. Kromatogram lapis tipis dari ${ }^{188} \mathrm{Re}$ seperti ditunjukkan pada Gambar 5.

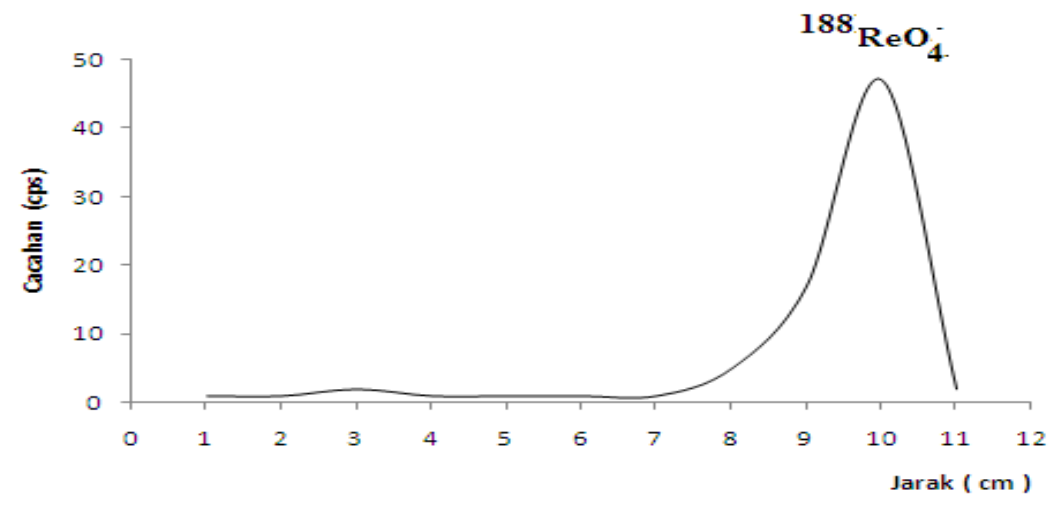

Gambar 5. Kromatogram lapis tipis ${ }^{188}$ Re menggunakan eluen aseton

Radioaktivitas diukur dengan alat pencacah Geiger Muller yang menunjukkan aktivitas ${ }^{188} \mathrm{ReO}_{4}$ - pada $\mathrm{Rf}$ $=1,0(13)$. Hasil perhitungan diperoleh kemurnian radiokimia ${ }^{188}$ Re lebih besar $95 \%$. 


\section{KESIMPULAN}

Hasil karakterisasi gel titanium tungstat secara gravimetri diperoleh rendemen $70,78 \%$ pada perbandingan mol Ti:W $=1: 0,71$, pembentukan gel terjadi dengan kondisi pengaturan $\mathrm{pH} 6$ dan suhu reaksi pada $60{ }^{\circ} \mathrm{C}$. Pemanasan $80^{\circ} \mathrm{C}$ terhadap gel tidak mengubah bentuk stuktur amorf, dan secara morfologi mempunyai warna putih, rapuh, butiran kasar serta homogen. Sedangkan apabila gel dikeringkan pada suhu $130{ }^{\circ} \mathrm{C}$, maka terjadi perubahan bentuk struktur melalui reaksi dehidrasi-oksolasi dari struktur amorf $\left[\mathrm{TiW}_{2} \mathrm{O}_{7}(\mathrm{OH})_{2}\left(\mathrm{H}_{2} \mathrm{O}\right)_{2}\right]$ menjadi kristal $\left[\mathrm{TiW}_{2} \mathrm{O}_{8}\right]$. Kehilangan kadar air didalam gel menyebabkan pelepasan ${ }^{188}$ Re mengalami kesulitan, akibatnya rendemen yang diperoleh akan kecil. Berdasarkan hasil karakterisasi tersebut bahwa kondisi optimum cara pembuatan gel titanium tungstat dan penggunaan eluen yang cocok akan berpengaruh terhadap pelepasan ${ }^{188}$ Re sebagai produk akhir.

\section{UCAPAN TERIMA KASIH}

Ucapan terima kasih disampaikan kepada bapak/ibu Yana Sumpena, Marlina, Nanih K, Nana S, Titin SM dan saudara Akhmad RS mahasiswa tugas akhir kimia-Unpad yang telah membantu penelitian ini.

\section{DAFTAR PUSTAKA}

1. A. MURRAY, M.S. SIMM, D.P. SCHOLFIELD, Production and characterization of ${ }^{188}$ Re-C595 antibody for radioimmunotherapy of transitional cell bladder cancer. J.Nucl. Med., 42(5) (2001) 726-732.

2. J.A. O'DONOGHUE, M. BARDIES, T.E. WHELDON., Relationship between tumor size and curability for uniformly targeted therapy with beta-emitting radionuclides. J.Nucl. Med., 36(10) (1995) 1902-1909.

3. R. MIKOLAJCZAK, M. ZUCHLINSKA. A. KORSAK, E. ILLER, D. PAWLAK, Z. ZELEK, M.KONIOR, J.L. PARUS, Development of a 188W/188Re generator. Technical Reports Series No.470, IAEA-Viena (2009) 175-185

4. H.M. TALAAT, A.A. EL-MOHTY, M.T. EL-KOLALY., Production of carrier free ${ }^{188}$ Re radioisotope generator based aluminum tungstate matrix. J Radioanal Nucl Chem, 28(4) (2010) 1-5.

5. J.A. OSSO,Jr, G. BARRIO, A. OLIVEIRA, B.S. MARCZEWSKI, V. MORAES, F. CAMARGO, R.C. NIETO, K.N. SUZUKI, C.R.B.R. DIAS, P.R.C. LOPES, N.C. SILVA, A.L.C.P. LIMA, B.L. FAINTUCH, J. MENGATTI, E. BORTOLETI, N.P. SOSA, C.P.G. DA SILVA, Development of ${ }^{188} \mathrm{~W}^{\prime 188}$ Re generator postelution concentration of $99 \mathrm{mTc}$ and evaluation of high capacity adsorbents, Technical Reports Series No.470, IAEA-Viena (2009) 107-111.

6. D. SETIAWAN, M. AGMA, Produksi renium-188 (188Re) dari generator ${ }^{188} \mathrm{~W} / 188 R$ Re menggunakan eluen asam askorbat. Bionatura Journal of life and physical sciences, 7(1) (2005) 12-21.

7. TSAI-YUEH LUO, L.O. AI-REN, BOR-TSUNG HSIEH, WUU-JYH LIN. A design for automatic preparation of highly concentrated ${ }^{188}$ Re-perrhenate solutions. Appl.Radiat.Isot, 65 (2007) 21-25.

8. S.K. SARKAR, M. VENKATESH, N. RAMAMOORTHY. Evaluation of two methods for concentrating perrhenate $\left({ }^{188} \mathrm{Re}\right)$ eluates obtained from ${ }^{188} \mathrm{~W}$-188Re generator. App. Radiat. Isot. (2008) 1-6.

9. LE VAN SO., C.D. NGUYEN, V.C. BUI, C.H. VO, Preparation of Inorganic Polymer Sorbents And Their Application In Radionuclide Generator Technology, Technical Reports Series No.470, IAEA-Viena (2009) 217-229.

10. F. MONROY-GUZMAN, W.E. BADILLO ALMARAZ, T. RIVERO GUTIERRES, L. GALLICO COHEN, J. COSGROVE, F.F. KNAPP,Ju, P. ROJAS NAVA, C.J. ROSALES, Development of inorganic adsorbents as matrices of generator for therapeutic radionuclides, Technical Reports Series No.470, IAEA-Viena (2009) 161-173.

11. M. FRAY, S. ABKOWITZ, S.M. ABKOWITZ, D.C. DUNAND, Microstructural and mecani-cal properties of Ti/W and Ti-6Al-4V/W composites fabricated by powder metallurgy, Journal of Material Science and Engineering, (2003) 344, 1-2, 103-112.

12. S. SEIFERT, H.J. PIETZSCH, The ${ }^{188}$ Re(III)-EDTA complex a multipurpose starting material for the preparation of relevant ${ }^{188}$ Re complexs under mild conditions, App. Radiat.Isot. 64 (2006) 223-227.

13. N. ZAINUDDIN, B. HIDAYAT, R. ILJAS, Pengembangan dan aplikasi klinis kit-kering radiofarmaka siprofloksasin. Jurnal Sains dan Teknologi Nuklir Indonesia.Vol.X, No.1, (2009) 1-10. 